\title{
Anticoagulant-related nephropathy: a common complication hiding in plain sight
}

Alyssa J Chamberlain ${ }^{1}$, Katie Carasco ${ }^{1}$, Alison Skene ${ }^{2}$, Terase Lancefield ${ }^{3}$, Peter F Mount ${ }^{1,4,5}$.

Departments of Nephrology ${ }^{1}$, Pathology ${ }^{2}$ and Cardiology ${ }^{3}$, Austin Health, Heidelberg, Australia.

${ }^{4}$ Department of Medicine, University of Melbourne, Austin Health, Heidelberg, Australia. ${ }^{5}$ Kidney

Laboratory, Institute for Breathing and Sleep, University of Melbourne, Heidelberg, Victoria,

Australia.

\section{Correspondence:}

Dr. Alyssa Chamberlain

PO Box 5555, Heidelberg VIC 3084, Australia

alyssa.chamberlain@austin.org.au

+61394965000

\section{Acknowledgements:}

None.

This is the author manuscript accepted for publication and has undergone full peer review but has not been through the copyediting, typesetting, pagination and proofreading process, which may lead to differences between this version and the Version of Record. Please cite this article Wardicounit:1420imj.15030

This article is protected by copyright. All rights reserved. 
Anticoagulant-related nephropathy: a common complication hiding in plain sight

Alyssa J Chamberlain ${ }^{1}$, Katie Carasco ${ }^{1}$, Alison Skene ${ }^{2}$, Terase Lancefield ${ }^{3}$, Peter F Mount ${ }^{1,4,5}$.

Departments of Nephrology ${ }^{1}$, Pathology ${ }^{2}$ and Cardiology ${ }^{3}$, Austin Health, Heidelberg, Australia.

${ }^{4}$ Department of Medicine, University of Melbourne, Austin Health, Heidelberg, Australia. ${ }^{5}$ Kidney Laboratory, Institute for Breathing and Sleep, University of Melbourne, Heidelberg, Victoria, Australia.

\section{Correspondence:}

Dr. Alyssa Chamberlain

PO Box 5555, Heidelberg VIC 3084, Australia

alyssa.chamberlain@austin.org.au

+61394965000

Acknowledgements:

This article is protected by copyright. All rights reserved. 
None.

Word count: 420

An 85-year old woman was referred with acute on chronic renal impairment detected prior to elective atrioventricular node ablation for atrial fibrillation. She had recently completed a course of amoxicillin for sinusitis, but had been otherwise well with no macroscopic haematuria and no changes to her regular medications. She had been anticoagulated on warfarin for six years with a recent international normalised ratio of 3.0. Serum creatinine had risen from a baseline of $200 \mathrm{mmol} / \mathrm{L}$ to $460 \mathrm{mmol} / \mathrm{L}$ over two months. Urine studies revealed haematuria ( $2022 \times 10^{6} \mathrm{RBC} / \mathrm{L}$ ) and a protein-creatinine ratio of $60 \mathrm{mg} / \mathrm{mmol}$. Autoimmune serology was negative and renal tract ultrasound showed a previously known atrophic left kidney. Renal biopsy showed extensive red cell casts and fresh red cells within the renal tubules with normal glomeruli by light and electron microscopy (Fig. 1). Warfarin therapy was ceased and the patient was discharged on an intermediate-dose of enoxaparin. Since discharge one month ago her renal function has consistently improved with a current creatinine of $300 \mathrm{mmol} / \mathrm{L}$. She is planned for insertion of a left atrial appendage closure device, aiming to facilitate cessation of systemic anticoagulants.

Anticoagulant-related nephropathy (ARN) should be suspected in patients on anticoagulation with unexplained acute kidney injury (AKI) and haematuria. Initially identified among patients on warfarin, there is mounting evidence that ARN also occurs with novel oral anticoagulants, though 
the risk may not be as high ${ }^{1}$. Whilst the true rate of ARN is uncertain, epidemiological studies suggest that it may be as high as $20 \%^{2}$, indicating that ARN is an under-recognised complication of anticoagulation. Risk factors include chronic kidney disease and over-anticoagulation ${ }^{2}$. Whilst mechanical obstruction of the renal tubules is believed to drive pathogenesis, the underlying molecular mechanisms remain unclear ${ }^{3}$. Renal biopsy confirms the diagnosis, demonstrating obstruction of the renal tubules by erythrocyte casts in the presence of normal glomeruli. Barriers to diagnosis include confounding risk factors for AKI such as cardiovascular disease and diabetes, and reluctance to perform renal biopsy on anticoagulated patients. A high degree of clinical suspicion is needed for this likely under-diagnosed condition. Management of ARN is predominantly supportive and may include reversal of coagulopathy, if safe to do so. Prognosis is variable, however most patients experience only partial recovery of renal function ${ }^{2}$.

This article is protected by copyright. All rights reserved. 


\section{References}

1 Brodsky S, Eikelboom J, Hebert LA. Anticoagulant-related nephropathy. J. Am. Soc. Nephrol. 2018; 29(12): 2787-2793.

2 Brodsky SV, Nadasdy T, Rovin BH, et al. Warfarin-related nephropathy occurs in patients with and without chronic kidney disease and is associated with an increased mortality rate. Kidney Int. 2011; 80(2): 181-189.

3 Yang Y, Liu T, Zhao J, Li G. Warfarin-related nephropathy: prevalence, risk factors and prognosis. Int. J. Cardiol. 2014; 176(3): 1297-1298. 
Fig. 1

Renal biopsy showing numerous tubular red cells casts in the absence of glomerular pathology.

Haematoxylin and eosin stain. Original magnification x200.

This article is protected by copyright. All rights reserved. 


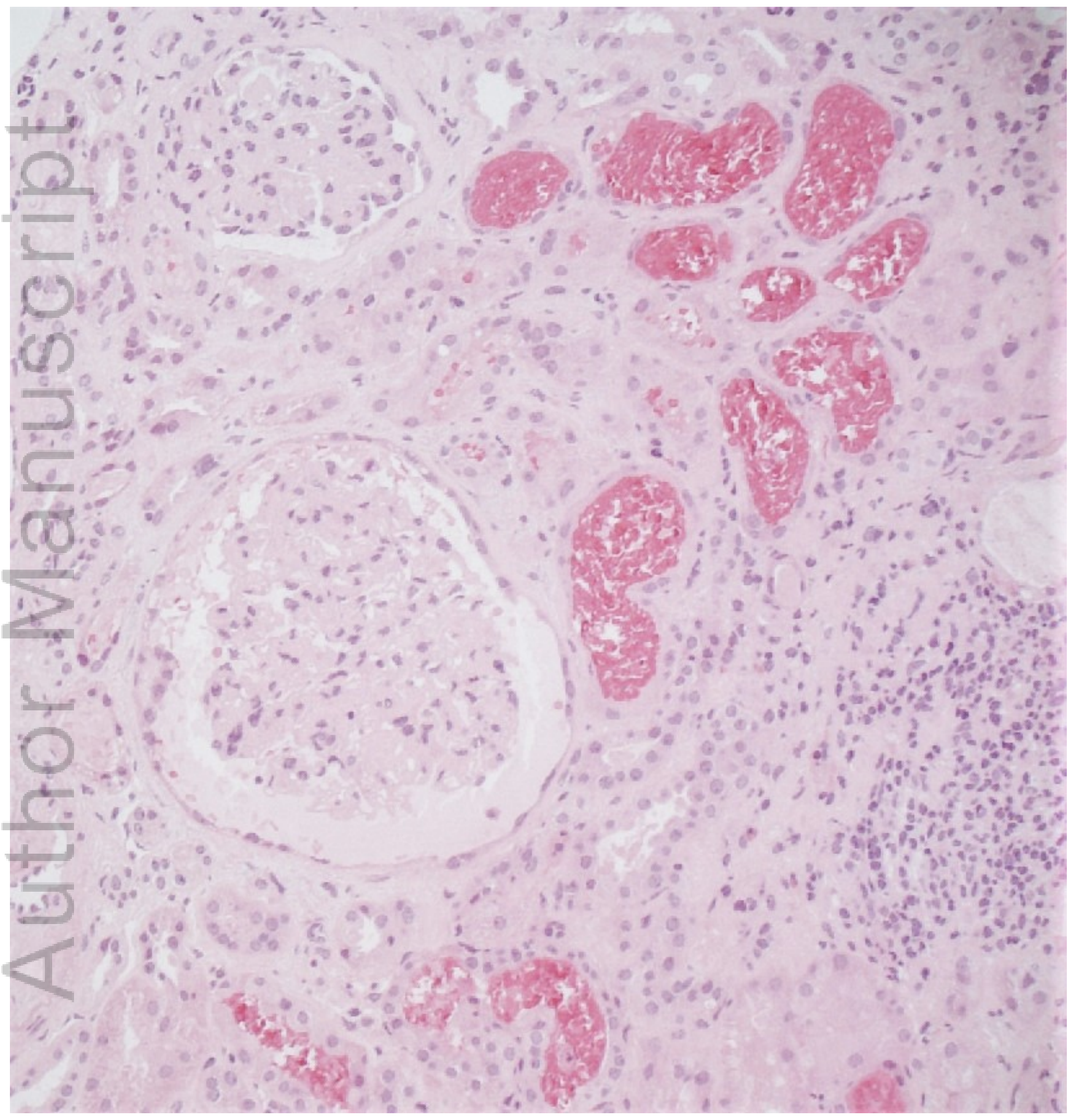

IMJ_15030_Figure 1.jpg

This article is protected by copyright. All rights reserved. 


\section{University Library}

\section{- M M N E R VA A gateway to Melbourne's research publications}

Minerva Access is the Institutional Repository of The University of Melbourne

Author/s:

Chamberlain, AJ;Carasco, K;Skene, A;Lancefield, T;Mount, PF

Title:

Anticoagulant-related nephropathy: a common complication hiding in plain sight

Date:

2020-10-01

Citation:

Chamberlain, A. J., Carasco, K., Skene, A., Lancefield, T. \& Mount, P. F. (2020).

Anticoagulant-related nephropathy: a common complication hiding in plain sight. INTERNAL MEDICINE JOURNAL, 50 (10), pp.1295-1296. https://doi.org/10.1111/imj.15030.

Persistent Link:

http://hdl.handle.net/11343/276393 